\title{
Problems and Countermeasures in the Cultivation of Craftsman's Spirit in Higher Vocational Colleges in the New Era
}

\author{
Yunshan Liu \\ School of Marxism, Wuxi Vocational Institute of Commerce, Wuxi, Jiangsu Province, China
}

Keywords: New Era; Higher Vocational Colleges; Craftsman's Spirit; Problems and Countermeasures.

\begin{abstract}
The report of the 19th National Congress of the Communist Party of China pointed out that we must promote "the spirit of model workers and the spirit of craftsmen". Therefore, higher vocational education in the new era must advance with the times to fully cultivate highly skilled workers with Craftsman's spirit. At present, the problems in the cultivation of the craftsmanship in higher vocational colleges are mainly reflected in the deviation of the concept of talent training, the lack of the pursuit of craftsman culture, and the imperfect evaluation system and mechanism of education and teaching. Therefore, the cultivation of craftsman's spirit in higher vocational colleges should be implemented from the aspects of changing the concept of talent cultivation, building a professional curriculum system, improving and implementing modern apprenticeships, and establishing an outstanding faculty.
\end{abstract}

\section{Introduction}

The report of the $19^{\text {th }}$ session of national congress of the communist party of China made it clear that the socialism with Chinese characteristics has entered a new era, and it has also made it clear that under the guidance of Xi Jinping's new era of socialism with Chinese characteristics, we should start a new journey of building a socialist modernized country. The report also pointed out that we must promote "the spirit of model workers and the spirit of craftsmen." In the new era, higher vocational education must be advancing with the times. With the guiding ideology of the report and the goal of "mass entrepreneurship and innovation", we must cultivate highly skilled workers with craftsman's spirit.

\section{The Concept and Meaning of Nurturing Craftsman's Spirit in the New Era}

Craftsmen are collectively known as skilled personnel who are skilled in a professional field, such as carpenters, masons, chefs, painters, first-line operators in modern factories, chief engineers, and so on. Their technical skills directly determine the quantity and quality of social products, as well as the quality of human life. Their craftsman spirit is an unparalleled pursuit of the perfect quality and the best quality of the products they produce. In the new era, we must vigorously promote the craftsman's spirit. Talent cultivation in higher vocational colleges should have the mission of nurturing craftsman's spirit in order to create thousands of technical and technical talents with craftsmanship. The cultivation of craftsman's spirit in higher vocational colleges is a systematic and comprehensive education and teaching innovation project. Cultivating craftsmanship is not only a professional education but also an ideological education. It mainly refers to cultivating the spiritual quality of craftsmen. Craftsman's spirit literacy includes professional pursuit of excellence and perfection, and the ideological realm of excellence and innovation.

Professional pursuit of excellence is to be serious, diligent, and diligent during the pursuit of professional knowledge and professional skills. In the use of professional skills, they should be meticulous and rigorous with each process and each step. The pursuit of perfection in occupation is a professional dedication to the work. It is reflected in the work of the products carved. To achieve the ultimate and perfect products, they are willing to devote decades of years even the whole life to their 
painstaking research. They regard the pursuit of perfecting products as the driving force for the work, thus realizing the dream of the great country craftsmen. The ideological realm pursues excellence and innovation is the pursuit of excellence, regarding innovation and development as a value pursuit, some kind of cultural pursuit. They always strive for self-improvement, work hard, respect first-rate and reject mediocrity. Excellence is some kind of realm. It is a state that brings out its advantages, capabilities, and resources to the extreme. In the pursuit of excellence in the development of innovation, they work hard and continue to forge ahead. The craftsmen will use their strong will to temper their aspirations and use their temperament to plunge into the noble sentiments of fine works, forging the fine qualities of the works and creating values for the pursuit of the cause. The ideological realm of pursuing excellence and innovation is to make the cause of advocacy into the heart, so that the pursuit of excellence and innovation can be integrated into the blood. The advocacy of the cause and the pursuit of excellence and innovation has become the motto.

\section{Problems in the Cultivation of Craftsman's Spirit in Higher Vocational Colleges in the New Era}

In the new era, the vocational colleges must cultivate high-quality skilled workers with the spirit of craftsman with innovation and practical abilities. At present, there are difficulties in cultivating high-quality skilled talents in higher vocational colleges and it is difficult to integrate innovation and practical abilities into personnel training. Higher vocational colleges should change their ideological concepts, guide the students scientifically, vigorously shape craftsman's spirit of teachers and students and train a large number of outstanding technical backbones for the new era to contribute to the nation's development from a manufacturing country to a manufacturing power.

Firstly, the concept of talent cultivation in higher vocational colleges tends to focus on cultivating innovative skills. Some higher vocational colleges pay more attention to the teaching of professional theory knowledge and professional technical skills in the concept of education. They fail to pay enough attention to the students' overall development and the cultivation of their innovative abilities. They also ignore the higher requirements for the teachers' ideology and abandon the edification and cultivation of students' craftsmanship.

Secondly, the managers and teachers of vocational colleges lack the pursuit of the craftsmanship culture. A large number of administrators and teachers in higher vocational colleges lack the systematic professional experience and the training of innovative abilities. Many managers and teachers also lack the professionalism, as well as the pursuit continuous innovation. They prefer to be satisfied with their present status. Their education and teaching management are conservative and not practical, lacking in-depth research and pursuit of higher vocational education and teaching management innovation philosophy in the new era. Their daily management and teaching professional theoretical course may be acceptable, but their innovation and practical lessons are inadequate. It is not effective for them to be a good example to cultivate the craftsman culture of excellence.

Thirdly, the evaluation system of education and teaching in higher vocational colleges has seriously affected the cultivation the teachers and students' craftsmanship. Under the current evaluation system, many higher vocational colleges attach importance to the evaluation of professional theory courses and the evaluation of teachers and students' education and teaching. They do not attach importance to the evaluation of the noble craftsman spirit literacy. Since the test scores of professional theoretical knowledge are qualified, there is no evaluation target system for the pursuit of the spiritual value of craftsmen. In the education and teaching of professional courses, a considerable number of students lack the momentum of excellence and assiduous study. They are passive in class and they often copy the others' after-school homework. In the practice courses such as training and practical training, a considerable number of students have the impetuous psychology of seeking swiftness, opportunism, eagerness for utilitarianism, eagerness to achieve success, sloppy learning. They lack the ideological awareness in pursuit of excellence. They are only satisfied with experimental data and know little about practical skills know. All these have seriously affected the effectiveness of the cultivation of craftsmanship in higher vocational colleges. 


\section{Strategies for Cultivating Craftsmanship in Higher Vocational Colleges in the New Era}

The education system of higher vocational colleges is in the middle of the modern vocational education system. It shoulders the mission of cultivating technical, skilled and talented personnel in production, management, construction and service. It is also a crucial stage for cultivating the talents of craftsmen. Therefore, the cultivation of the spirit of craftsmen in higher vocational colleges should be implemented from the aspects of changing the concept of talent training, building a professional curriculum system, perfecting and implementing modern apprenticeship, and establishing an outstanding teaching team.

Firstly, changing the concept of talent cultivation is a prerequisite for cultivating craftsmanship. Higher vocational colleges should adapt to the needs of the development strategy in the new era and cultivate a large number of highly skilled personnel with craftsman's spirit. This requires the managers in higher vocational colleges to change their concepts and to unify their ideas and ideas for running schools to achieve the strategic objectives of national economic and social development. Now higher vocational education plays a decisive role in talent cultivation. However, in the concept of running a school, there are still many deviations in higher vocational education. Many higher vocational colleges regard setting up excellent colleges and model colleges as the goal of running a school. Higher vocational colleges lack special features in professional setting and have no long-term development goals. All these have led to the rapid decline of some professions. In vocational colleges that do not have the characteristics of running a school and lack professional expertise, it is impossible to nurture talented craftsmen who have the craftsman spirit in their field of profession and technology. Therefore, higher vocational colleges must change the concept of personnel training, specify the training objectives of various professionals and regard fostering craftsman's spirit of teachers and students as an important guiding ideology for running schools. They should combine professional characteristics and advantages to achieve the characteristics of running higher vocational education, and continuously enhance social service capabilities and levels to promote the regional economic and social development. Only in this way, can we continue to nurture highly-skilled high-tech talent with the spirit of craftsman.

Secondly, the construction of the corresponding professional curriculum system is the basic support for the cultivation of craftsmanship. Cultivating technical and technical talents with craftsman's spirit is an important goal for the cultivation of talents in higher vocational colleges. It runs through the entire process of talent cultivation and is reflected in professional curriculum setting, curriculum teaching and some other aspects. On one hand, the colleges should combine craftsman culture to build a system of craftsman spiritual literacy training courses. The craftsman culture contains the craftsman spirit. And the craftsman craftsmanship is the core of the craftsman culture. Professional teachers are required to deeply analyze and study the professional spirit of craftsman. They shall use the spirit of craftsmen as the main line and use professional culture and professional humanities as the link to build a teaching platform for craftsman spiritual literacy education. The cultivation of literacy should be closely integrated with the education and teaching of professional courses, as well as the teaching objectives, teaching contents and the assessment rules of professional courses. The colleges should also build a specialized curriculum system for the development of craftsman spiritual literacy. Through the establishment of the curriculum system, the entire professional curriculum education and teaching process not only meets the requirements of technology transfer, but also meets the requirements for the development of craftsmen's spiritual literacy. On the other hand, based on the characteristics of different professional courses and synchronize the craftsman spirit literacy education in education and teaching. Professional courses are the most important channel and carrier for the development of the craftsman's spiritual literacy. In-depth participation of professional teachers is the leading force for the growth of the craftsman's spiritual literacy. In the daily professional curriculum education and skills training, the professional teachers should fully explore the craftsman's spiritual literacy and traits inherent in the professional knowledge and technology system and infiltrate the spiritual beauty, technical beauty, and creative beauty of the craftsman spirit literacy in education and teaching. They must attach importance to the effectiveness of curriculum teaching and pay attention to the value of curriculum teaching. They 
should not only allow the students to improve the quality of craftsmen, but also enable the students to achieve the transcendence of the craftsman's cultural tastes. They should not only allow the students to gain professional knowledge and enhance their professionalism, but also help the students pursuit for professional ethics, professionalism and career and other craftsman spiritual accomplishment.

Thirdly, perfecting and implementing the modern apprenticeship is an important vehicle and platform for cultivating craftsmanship. The cultivation of craftsman's spirit in higher vocational colleges is the accumulation of practical training, which is the result of the cultivation of the first-line craftsman culture of the company. Therefore, modern apprentice production is a collaborative model of talent cultivation for schools and enterprises. It integrates practical education, model education and education for fostering the spirit of craftsmanship. It can guide the teachers and students foster the cultivation of craftsmanship throughout the process of learning and practicing craftsmanship and make it blended with professional technology learning. Modern apprenticeship is a new model for vocational colleges to cultivate technical talents. In this model, the students are apprentices. They are the education and teaching objects and the corporate mentors and school mentors jointly impart them knowledge and skills. The prominent feature of modern apprenticeship is learning in doing and doing in learning. The students can learn the theoretical knowledge while learning the operation of professional and technical skills, emphasizing the understanding and mastery of theoretical knowledge and operating skills, which is conducive to cultivating the students' excellence and pursuit, the ultimate craftsman's spiritual literacy. Therefore, higher vocational colleges must the best use of the special role of modern apprenticeship in cultivating craftsmanship. The modern apprentice production is an important carrier and platform for fostering craftsman's spirit in higher vocational colleges. It is the realization of a series of norms and standards for apprentices by enterprise and business instructors. The company and enterprise mentors will restrict the students' ideological behaviors by formulating practical training work, provide the conditions for cultivating craftsmanship and guide both teachers and students to continuously learn and practice craftsmanship through formulating academic assessment standards and corporate recruitment standards that focus on craftworker spirit inspections. In the model demonstration of corporate mentors and their own personal experience, the students will gradually internalize the craftsman's spiritual literacy with excellence and unique.

Fourthly, the establishment of an excellent team of teachers is an important guarantee for fostering the spirit of craftsman. The excellent teachers are the implementers, reformers and builders of education and teaching. The cultivation of craftsmanship in higher vocational colleges mainly depends on an excellent team of teachers. Therefore, the establishment of an excellent teacher team, as well as the continuous enhancement of their professional qualities and the improvement of their innovative practical ability, can provide supporting for the cultivation of college students' craftsmanship. The establishment of outstanding teaching staff is a long-term and systematic process. Higher vocational colleges should not only base on the actual conditions of the school, but also combine the strategic needs of the country's economic and social development, and constantly explore the effective path for the establishment of an outstanding teaching staff to promote higher vocational college education. The goal of training talents is to cultivate high-quality technical and technical talents with the craftsman's spirit, and the inheritors and successors of large-scale craftsmen. The outstanding teachers in higher vocational colleges must have a profound theoretical foundation and strong practical ability, as well as the ability to guide the students' practice. The structure of the outstanding teachers in higher vocational colleges must be combined specifically and exclusively. Part-time teachers mainly come from the technical backbone of the company's frontline. They are both skilled craftsmen in the enterprise and the mentors of professional practice guidance for college students. The company's part-time mentor plays an important role in cultivating technical and technical talents and strengthening the connection between schools and society, which can provide powerful guarantee for the cultivation of craftsmanship in higher vocational colleges.

\section{References}

[1] X. Y. Liu. Analysis of the Construction of Spiritual Cultivation System for Craftsmen in Higher 
Vocational Colleges [J]. Data of Culture and Education, 2017, 17.

[2] X. G. Zhang. The Value, Embarrassment and Excavation of the Craftsman's Spirit in Higher Vocational Colleges [J]. Education and Vacation, 2017, 21.

[3] J. Li. Research on the Contemporary Value of the Craftsman's Spirit and Its Cultivation Path [J]. Chinese Vocational and Technical Education, 2016, 27. 